\title{
Practical Reason and Respect for Persons
}

[forthcoming in Kantian Review]

Melissa McBay Merritt

University of New South Wales

\section{Introduction}

My project in this paper is to reconsider the Kantian conception of practical reason. Some Kantians suppose that practical reason must be more radically self-determining than theoretical reason, in the sense that it need not contend, in its sound exercise, with what is there anyway, independently of its exercise. The idea that lies behind this claim is that practical reason is essentially efficacious: it does not merely determine its object — the good — but also brings it into being. Call this the efficacy principle; I will accept it. But I will deny that it entails that practical reason need not contend, in its sound exercise, with what is there anyway.

The case that I will make against this view of practical reason will focus on the significance of respect for concrete, empirically available persons. Suppose a student just walked into my office: my recognition that here is a person engages a range of normative requirements on my conduct, requirements that I must meet if I am to realize, or bring about, the good in what I do. But the particular person is not herself this good, the good to be brought about in what I do. Moreover, it is, at least in some sense, a given fact that there is a person here now; and my being apprised of this fact, my recognizing it, is possible surely owing to some sort of receptivity on my part. Further, the fact of any person's existence seems to be a fact that obtains anyway, independently of any particular exercise of practical reason - and thus regardless of whether I act well or badly. And yet it would seem to be a fact that needs to be taken account of in the right way if I am to act well. If that is right, then the recognition of persons as persons puts pressure on the assumption that practical reason is, by Kantian lights, more fully active than theoretical reasoning, on the grounds that it need not contend with what is there anyway. Concrete, empirically available persons are there anyway, in the relevant sense. 
The view about practical reason that I aim to reject has figured as a driving force on one side of the metaethical debate that has broken out among Kantians in recent years. One party to this debate claims Kantian metaethical commitments are properly anti-realist, or constructivist. These constructivists emphasize that practical reason is essentially efficacious; this is what distinguishes it from theoretical reason. ${ }^{1}$ Further suppositions about the nature of practical reason appear to follow from this claim. Christine Korsgaard takes issue with a conception of reason that she attributes to moral realists, who 'think that practical reasoning is no more active than theoretical reasoning' — a view she pointedly rejects (2008:10). Likewise Stephen Engstrom calls for the rejection of 'the assumption that reason, the cognitive capacity itself, is receptive in nature and passive in operation' - an assumption that, in his view, stands in the way of our coming to terms with practical reason's essential efficacy, i.e., that it brings its own object into being (2009:13-14). ${ }^{2}$ By contrast, the distinction between theoretical and practical reason does not seem to be a point of particular interest on the realist side of this debate. Still, the realists might be read as maintaining that sound exercises of practical reason must take account of moral facts that obtain anyway, independently of any exercise of practical reason.

My own inquiry here will be conducted against the background of that debate — though I will not, for reasons that I will explain, weigh in on it directly. In my view, both parties to this debate correctly point to distinct issues that need to be accommodated in any Kantian account of practical reason: the problem is how to combine them into a coherent view with a clear Kantian provenance. The crux of this paper consists in a proposal for doing just this. As we will see, it will commit me to a certain kind of empirical moral realism — but not one that amounts to an endorsement of Kantian moral realism as a hard metaethical position.

I begin by setting out the Kantian metaethical debate, in order to bring my own topic and agenda into sharper view $(\$ 2)$. Then I offer a proposal for how the relevant claims from opposing parties to this debate might be jointly accommodated (\$3). The remainder of the paper 
(\$\$4-5) aims to make good on the Kantian provenance of my proposal, and to indicate how it challenges standing assumptions about the Kantian conception of practical reason.

2. Practical reason and the Kantian metaethical debate

My topic in this paper is, most fundamentally, what we should make of the Kantian conception of practical reason. The contemporary Kantian metaethical debate is instructive for this purpose, since the opposing parties conceive of practical reason in somewhat different terms. My own proposal will draw a central point from each, and I will defend its Kantian provenance. Ultimately this stands to advance our understanding of both Kant and contemporary Kantian metaethics alike. So I begin with the metaethical debate.

Kantian constructivism takes Kantian metaethical commitments to be anti-realist: the right and the good do not exist independently of us, what we do, and how we choose.

Somewhat more precisely the view is that the right and the good do not exist independently of the exercise of practical reason — since, we might imagine, practical reason could be found in beings other than us. For Rawls, Kant taught us that there is no 'independent order of values'.

The arguments that Kantian ethics is committed to metaethical anti-realism have been various. One basis for argument — the one that interests me here - concerns the nature of practical reason and its distinction from theoretical reason. ${ }^{4}$ On one occasion, Kant glosses that distinction by saying that theoretical knowledge concerns 'what exists [was da ist]', whereas practical knowledge concerns 'what ought to exist [was dasein soll]' (A633/B661). ${ }^{5}$ But he gives some indication that he takes that gloss to be provisional, ${ }^{6}$ presumably because this account obscures the fact that the two modes of knowledge relate in distinct ways to their objects. ${ }^{7}$ Theoretical reason judges about objects that are there anyway, independently of its exercise: its objects are the spatiotemporal particulars of material nature. By contrast, Kant says, for practical reason 'to determine' its object is 'also [for it] to make it actual' (Bix-x). ${ }^{8}$ Kant says that the sole objects of 
practical reason are the good and the evil (das Gute and das Böse, KpV 5:57-60): the good as what is to be realized, and the evil as what is to be avoided, in action according to a rational principle. So understood, the good and the evil that are the objects of practical reason are not objects that are there anyway, independently of any exercise of practical reason. That is why Kant says that the exercise of practical reason does not merely determine its object — the good — but also makes this good actual.

Continuing this line of thought, the constructivist then directs attention to Kant's remarks about the methods of ethics in the Critique of Practical Reason, where Kant explains why an account of the good can only be derived from a prior account of the principles of practical reason (5:62-3). ${ }^{9}$ It cannot go the other way around: first an account of the good, and then an account of practical reason's capacity to track the good that exists independently of it. Such procedures can only underwrite 'heteronomous' moral theories, Kant goes on to argue, since they all operate under the assumption that the role of reason is to work out the means to this independent good (5:64). Such theories effectively leave reason beholden to the good as a kind of external authority over its own operations. On the received view, a certain conception of practical reason underwrites a story about the possibility of autonomy; and the whole package requires, in turn, the rejection of moral realism.

Critics of constructivism suggest that it faces a challenge from Kant's remarks about the objective and unconditioned value of autonomy, and humanity insofar as it is capable of autonomy. It may well be that the value of sailing, or studying philosophy, depends upon the choices that we make; but the value of autonomy, or of humanity insofar as it is capable of autonomy, is not itself dependent on the exercise of practical reason, as the thoroughgoing Kantian constructivist would maintain. ${ }^{10}$ Kant took autonomy, and humanity insofar as it is capable of autonomy, to have objective and unconditioned value; and this value, Kantian moral realists maintain, is discovered — not created — through the exercise of practical reason. ${ }^{11}$ It is the value that practical reason is attentive to — respects, we might say — when it is exercised well. 
Drawing attention to this line of thought, Allen Wood takes it to yield 'as unequivocal an assertion of metaethical realism as you could ask for' (2008:112), ${ }^{12}$ and provocatively dismisses 'the term "Kantian constructivism in ethics" as an oxymoron, whose interest ought to lie exclusively in its shock value' (2008:46).

To uncover the source of this debate, we must first identify the Kantian common ground. Normative thoughts are characteristically expressed as obligations of some kind: one ought to do this or that, or adopt a certain end or attitude. If metaethics generally aims to give an account of what it is to think a normative thought, then a Kantian metaethics would account for this as a matter of knowing something. For a Kantian, thoughts of the form 'I ought to $\varphi$ ' must be such as could be true or false. Constructivists have questioned whether truth is an appropriate notion here ${ }^{13}$ but I think it should be possible to speak of 'truth' with a light hand, and so without prejudice to the debate, as conformity with a necessary standard of correctness. For a Kantian, a true normative thought identifies something that is required of one as a rational agent (the requirement is 'categorical'), and hence is required of anyone. ${ }^{14}$ One might have a thought in the form 'I ought to $\varphi$ ', but unless it identifies some such requirement, then strictly speaking it is not true but only the expression of what one has overriding reason to do in light of one's own preferences, which themselves rest on contingencies. To be true, then, a normative claim must be true of - in the sense of hold for — any rational agent. And that can only be understood through an account of what it is to be a rational agent. That is why opposing parties in the metaethical debate will alike appeal to facts about rational nature as grounding normative truths.

This means that much of what might be taken to be 'moral realism' in non-Kantian quarters should be uncontroversial within Kantian quarters. Suppose we take moral realism to consist in the combination of cognitivism and the rejection of error theory that we get if we maintain that moral claims are literally true or false, and some of them are indeed true (SayreMcCord 1988). This might be trivially attributable to any Kantian position — at least any that 
takes seriously Kant's conception of practical reason as a cognitive capacity issuing in moral knowledge (cf. Formosa [2011:172]). ${ }^{15}$ Or suppose that we take moral realism to consist in the view that at least some moral truths hold independently of us. How a Kantian might work with this depends, of course, on the unpacking of 'independently of us'. Yet it seems clear that Kant himself repeatedly invokes an idea of this sort, by distinguishing between practical reason as such — or as it would be in a perfectly rational being — and practical reason as it is in finite creatures such as us. ${ }^{16}$ So there might be some uncontested sense in which the Kantian position is realist, because appeal can be made to whatever is attributable to reason as such as the basis for making claims about moral truths that obtain independently of the human standpoint.

According to Kantian common ground, the truth of any particular normative claim can only be determined by constitutive principles of practical reason - i.e., the moral law, which for imperfect rational beings figures as the categorical imperative. But to say this only papers over the metaethical disagreement. It might be read as saying that these moral truths themselves obtain through the sound exercise of practical reason: that is the constructivist option. Or it might be read as saying that these moral truths are there anyway, only discovered through the sound exercise of practical reason: that is the realist option. ${ }^{17}$

Any Kantian will attribute the truth of any particular claim to its conformity to moral requirement as determined through the categorical imperative. So the metaethical debate can only concern the status of the categorical imperative itself. The metaethical realist claims that some independent moral fact makes the categorical imperative true: it is the value of the capacity to set ends and act on them, and hence the value of creatures with practical reason. To this the Kantian constructivist replies that we should reject even this appeal to brute given value. For the constructivist, a normative thought that stands in the right relation to the constitutive principle of practical reason is one that enables a rational being to solve some fundamental practical problem. That is why the categorical imperative is a good rule, and not because it enables us to 'pick out', somehow, what has objective and unconditioned value. ${ }^{18}$ 
What is at stake in the Kantian metaethical debate, then, is the truth-maker of moral knowledge. One party to the debate denies, whereas the other maintains, that the Kantian position necessarily makes appeal to some independent fact about what has objective and unconditioned value. My interest in the debate lies not in proposing a solution, ${ }^{19}$ but rather in unearthing its driving assumptions about practical reason.

From the outset, I noted that the question of how to distinguish theoretical and practical reason receives lopsided attention in this debate. While Kantian moral realists seem not to dwell so much on the distinction, a constructivist such as Korsgaard builds an argument for metaethical anti-realism on a view of what makes practical reason special. Korsgaard also charges moral realists with lacking the resources to tell the two apart; ${ }^{20}$ and since Kant's entire critical project is built around the distinction, the charge from constructivist quarters would then be that a position that cannot tell the two apart must fail to be a genuinely Kantian one.

On the other end, the realist puts up resistance to the constructivist's claims about the object of practical knowledge — particularly to the idea that this object, the good, is brought into being through the sound exercise of practical reason. The moral realist mounts this resistance from what appears to be a perfectly sensible position about what knowledge — speaking quite generally — should involve: an object of knowledge must be something that obtains independently of any particular effort to come to cognitive terms with it. Bring that to bear on the possibility of practical knowledge, and we should get the following result. Some objective and unconditioned value obtains quite independently of any particular exercise of practical reason independently of anything that anyone might do or fail to do. After all, if there is no sense in which exercises of practical reason owe allegiance to what is there anyway, then how can the determination of the good be anything but arbitrary? ${ }^{21}$

In my view, each side identifies something that ought to figure in any Kantian conception of practical reason. The constructivist is right to point to the essential efficacy of practical reason; and the realist is right to suggest that practical reason, in its cognitive exercise, 
should owe allegiance to what is there anyway, independently of any particular exercise of it. In the next section, I will offer a proposal for how these two claims might be combined. After that, I will try to make good on the Kantian provenance of my proposal, and explain how it bears on the nature of practical reason.

\section{The proposal}

My proposal relies on a general claim about knowledge. It can be roughly summarised along the following lines: to have knowledge requires that one's thinking in regard to an object be constrained by how things are with that object. With this in mind, we should find ourselves compelled to say that the object of knowledge is there anyway, independently of any particular effort to come to cognitive terms with it. I will refer to this as the there anyway requirement. If practical reason is a cognitive capacity, why should its exercises - at any rate those that issue in knowledge — not be held to this requirement? I think they should. The puzzle is to work out how, without undermining the idea that practical knowledge is essentially efficacious.

On the face of it, accepting the efficacy principle seems to entail that the there anyway requirement is unworkable for practical knowledge. ${ }^{22}$ For if we accept efficacy, then it follows that the object of practical knowledge is not there anyway, independently of any exercise of the relevant cognitive capacities. Now, the traditional Kantian moral realist rejects efficacy. So when Kant claims that practical knowledge makes its object 'actual', they cannot take this to mean that such knowledge brings its own object into being. For this realist, practical knowledge can only instantiate some independent good; thus, by appeal to the independence of the object of practical reason, these realists can maintain that exercises of practical reason are held to the there anyway requirement. However, it is possible to hold exercises of practical reason to the there anyway requirement without accepting the realist metaethical position about the independence of the object of practical reason. For even if realism is false, so that the object of practical reason is 
not there anyway, something else is there anyway — namely, actual persons. My aim in this section is to draw upon this idea in order to explain how the essential efficacy of practical reason can be admitted while also holding its cognitive exercises to the there anyway requirement.

My proposal relies on Kant's claims about the objective and unconditioned value of persons. To borrow from Langton's (2007) presentation of the example of Maria von Herbert, a noblewoman and philosopher who corresponded with Kant in the 1790s: we might suppose that this Maria is loved or valued by no one (she is depressed about a failed relationship), that she no longer takes any interest in anything, and finally that she no longer values herself. If Kantian moral cognitivism maintains that we can have moral knowledge, and that to have such knowledge is to adopt the appropriate attitude towards what is of objective and unconditioned value, and if persons have such value, then the value of Maria should obtain quite independently of anything that anyone — including Maria — does or fails to do.

What does it mean to suppose that Maria has such value? To say that she has value objectively presumably entails that she ought to be valued by anyone (whether or not she is). To say that she has value unconditionally presumably means that her value is not dependent on anything anyone does or does not do (including herself). This is a highly general formulation that does not weigh in on the real challenge of moral life, which is to appreciate what the fact of any person's existence requires of one in any given instance. All it says is that the fact of a person's existence is a constraint on practical thinking, inasmuch as such thinking is to be practical knowledge.

My proposal calls for us to distinguish the fact of any person's existence from the object of practical reason. Suppose again that someone has walked into my office, and I recognize that here is a person: I appreciate the fact of a person's existence. What Kant refers to as 'the object' of practical reason must lie in the quality of my engagement with this person. Very roughly, and abstracting from every difficult question of moral life, the object is good if I treat her in a way befitting her dignity as a person. But this person standing in front of me is not herself the object 
of my practical deliberation: she is not the good that I might bring about, or instantiate, in what I do. ${ }^{23}$ She is there anyway, whether I act well or badly. Exercises of practical reason, if they are to count as knowledge, owe allegiance to such facts; and in this way, exercises of practical reason can be held to the there anyway requirement. That is my proposal.

Let me underscore some things. From the constructivist, I accept that practical reason is essentially efficacious. So I accept that the fundamental moral reality — the object of practical reason — is the good that is brought about through action. Now, presumably constructivists would grant that exercises of theoretical reason are held to the there anyway requirement, and acknowledge that theoretical reason has a receptivity proper to its exercise; they expressly deny that practical reason is held to this requirement, and so that it has any receptivity proper to its exercise. I will challenge this, arguing that the concrete recognition of a person's existence has the marks of a receptive engagement of the relevant cognitive capacities. In my example, the object of this receptivity is the person who has just walked into my office, whereas the object of active practical deliberation is something like a good interaction with this person. My proposal calls for distinguishing the object of practical receptivity from what Kant points to as the object of practical knowledge (the good). The object of practical receptivity — the relevant fact about a person's existence — is available to meet the there anyway requirement. The object of the active, deliberative engagement of practical reason remains the good to be brought about through action. Thus I address the concerns that the moral realist raises about arbitrariness. I register those concerns by claiming that any concrete exercise of practical reason — if it is to be genuinely cognitive - involves a responsiveness to what is there anyway.

My proposal accepts something about practical reason from each side of the Kantian metaethical debate; but it also remains neutral in that debate. As I explained (\$2), that debate turns on whether or not some independent value underwrites the status of the categorical imperative as the moral law. The realist side appeals to an independent fact about value to underwrite the categorical imperative; the constructivist denies that there can be any such 
independent facts about value, and instead claims that constitutive requirements on the exercise of practical reason yield the only moral facts that there are. For the constructivist, the categorical imperative commands every possible rational being to value Maria: that is where her value comes from, and that is why it figures, at ground-level, as objective and unconditioned. If it were a bedrock fact about practical reason that any engagement of it should entail some commitment to care about small round stones, then at the ground-level perspective, small round stones would show up as being intrinsically valuable. Their value would not be dependent upon how anyone acts or thinks; it would have to do only with the constitutive principles of practical reason as such. Of course, no Kant-style derivation of the principles of practical reason could show that small round stones have objective and unconditioned value. The point is just that nothing in what I have proposed about the receptivity of practical reason is inconsistent with this style of metaethical constructivism. But although my proposal does not require me to take a stand in the metaethical debate, still my proposal might count as some order of realism — empirical moral realism — owing to its appeal to the there anyway requirement.

Next I will adduce textual evidence for my proposal. As noted, my proposal calls for distinguishing the fact of any person's existence from the object of practical reason: in $₫ 4.1, I$ show that Kant is committed to this distinction. How this distinction bears on the problem at hand — what to make of the Kantian conception of practical reason — depends upon how facts about the existence of persons are apprised, and (in turn) what sort of facts they are. I address these issues in $\$ 4.2$, where I argue that such facts are apprised through (what we can call) 'recognition respect', and that this should be by Kant's lights be a distinctly practical receptivity. The implications of all this for the Kantian conception of practical reason will be drawn out more fully in $₫ 5$. 


\section{Textual evidence}

\subsection{The value of actual persons distinguished from the object of practical reason}

I have already drawn attention to Kant's view that the object of practical reason is the good to be brought about through action. Appealing largely to common sense, I have noted that actual persons - certainly actual other persons — cannot be the object of practical reason, so conceived. The student who walks into my office is not herself the good to be brought about through what I might then do or not do. She is 'there anyway', whereas the object of practical reason cannot be 'there anyway'. The object of practical reason would, presumably, lie somewhere in the quality of my engagement with her. Now, Kant speaks of persons as having objective and unconditioned value. My aim in this subsection is to show that Kant himself is committed to distinguishing the value of actual persons from the object of practical reason.

Traces of this distinction can be found in the Groundwork, as Kant sets about establishing the statement of the categorical imperative commonly known as the 'formula of humanity'. We do not need to get into the details of Kant's derivation of the formula of humanity here. We simply need to note the distinction that he draws, in the course of his argument, between ends that are 'to be effected' versus 'independently existing' ends: bewirkende as opposed to selbstständige Zwecke (G 4:437). ${ }^{24}$ Ends of the latter sort, Kant continues, must be 'thought only negatively, that is, as that which must never be acted against and which must therefore in every volition be estimated never merely as a means but always at the same time as an end' (G 4:437). ${ }^{25}$ The context of the remark indicates that these independently existing ends are persons, rational beings; ${ }^{26}$ the upshot is that the fact of any person's existence constrains choice. Kant said as much earlier on: 'the human being and in general every rational being exists as an end in itself and so is not to be used as mere means - and is thereby 'an object of respect', and as such 'limits all choice' (G 4:428). ${ }^{27}$ Consider again the student who has just walked into my office. My recognition here is a person engages a range of normative requirements on my conduct, requirements that I must meet if I am to realize, or bring about, the good in what $\mathrm{I} \mathrm{do}^{28}$ The 
recognition here is a person is, in the first place, a constraint upon choice: here is some reality that I must not 'act against'.

Now, when Kant says that independently existing ends are 'thought only negatively' he thereby implies that ends to be effected are thought positively. What would this mean? I take it that an end that is thought positively figures as something to actively go for. So there is a difference between not 'acting against' another person and, say, taking an active interest in her happiness. If I make her happiness my own end, this must be the sort of end that is 'to be effected'. How, then, would Kant's conception of the object of practical reason map onto these remarks? If this object is the good to be brought about through, or realized in, action, then presumably it stands to figure for a deliberating agent as an end to be effected, rather than an independently existing end. If so, then the distinction that Kant draws between ends to be effected and independently existing ends provides evidence that he draws the distinction that my proposal requires (i.e. between the object of practical reason and the value of actual persons).

Some might resist this. After all, Kant remarks in this same stretch of the Groundwork that 'the worth of any object to be acquired [zu erwerbenden Gegenstände] by our action is always conditional' (4:428). If the object of practical reason is the good to be brought about through, or realized in, action, then it would seem to follow from this remark that its goodness is conditional. But this would give us an interpretive reductio ad absurdum. So either something has gone deeply wrong from the beginning, or else further clarification is in order. Indeed, further clarification about the object of practical reason is required. For this object is not a good that is to be acquired by action; rather it is a good that is internal to action, and so in that sense to be realized in action. To show why this matters, let me first elaborate on why the object of practical reason should be thought as an end to be effected.

As I have noted, Kant implies that an end to be effected is thought positively: it figures as what one actively goes for, rather than as something that merely constrains choice. In this stretch of the Groundwork Kant suggests that the positive determination of an end depends either 
upon the presence of (a) an 'incentive', when we value something subjectively as an object of inclination; or (b) a 'motive' — here a technical term that Kant glosses as 'the objective ground of volition' (G 4:427). So there are two ways in which an end can figure positively, as an end to be effected: either through incentive, or through motive (a determination of choice by the moral law). Together they are distinguished, as ends to be effected, from the 'independently existing' or 'self-standing' end that Kant says is thought only negatively, as something never to act against. Such an end is 'self-standing' because it is not relative to (does not depend upon) any particular act of willing or choice.

To make this a bit more concrete, return again to our running example of the student who has just walked into my office. If I take an active interest in her welfare, then I make her happiness my own end. In the Doctrine of Virtue of the Metaphysics of Morals, Kant argues that virtue is the good character that can arise only from the free adoption of certain morally obligatory ends; there are two such ends: one's own perfection and the happiness of others. ${ }^{29}$ If I make the happiness of this student my own end, I must be thinking this end positively, as something to go for. It is therefore an end to be effected. But how do I come to think the end of her happiness positively, as something to go for? I may think this end positively, as something to go for, because I am so inclined. Or I might think this end positively on some other grounds: namely, because I freely adopt the morally obligatory end of the happiness of others.

Strictly speaking, Kant says, 'only the way of acting, the maxim of the will, and consequently the acting person himself as a [...] human being' can be called good (KpV 5:60). The good, as the object of practical reason, lies in the manner of acting, and thus is internal to it. It is not something that is to be acquired by action (as a separate result), but a good to be realized in action. Return again to our running example. The good internal to my action, if there is any, would lie in the way of acting — and so, for example, how I think the end of her happiness. The value of her happiness as something that might result from what I do is a separate issue. Here Kant's claim that the value of any object to be acquired through action can only be conditional 
(G 4:428) applies. Indeed, that is exactly what Kant goes on to say: her happiness, like any happiness, has a worth that 'always presupposes morally lawful conduct as its condition', i.e. a value conditional upon desert (KpV 5:111).

Kant also says that 'good [...] always signifies a reference to the will insofar as it is determined by the law of reason to make something its object' (KpV 5:60). So conceived, the good stands to figure as an end to be effected. The value at issue relates to acts of choice, or a general disposition or character that expresses itself in acts of choice. It is distinguished from whatever value persons may have simply as 'independently existing ends' — a formulation that indicates the value at issue obtains independently of any particular determination of choice.

\subsection{Recognition respect}

My proposal requires that we distinguish the value of actual persons from the object of practical reason; and I have just shown how Kant is plausibly committed to that distinction. Now I want to look into the question of how, by Kant's lights, facts about the existence of persons are apprised. I will argue that they are apprised through (what we can call) recognition respect. To explain what this is, and its place in Kant's ethical thought, it will be necessary to consider the topic of respect more broadly. Against that background, I will argue that recognition respect is a distinctly practical receptivity: indeed, it is a receptivity required for any concrete exercise of practical reason.

Kant's account of respect undergoes shifts in emphasis over the course of his career. To track it correctly, it will help to identify a general notion of respect, and distinguish two further species of it - one of which is the recognition respect at issue. Respect as such is simply the readiness of a human being (or any finite, embodied rational being) to be moved by his appreciation of moral requirement. Kant says that respect is '[i]mmediate determination of the will by means of the law and consciousness of this' (G 4:401n). Appreciation of moral 
requirement brings with it — directly, or immediately — some readiness, even if not sufficient, to act accordingly.

When Kant introduces the notion of respect in the Groundwork, he says that the 'object of respect is $[\ldots]$ simply the [moral] law' (4:401n). Further, he says there that '[a]ny respect for a person is properly only respect for the law (of righteousness [Rechtschaffenheit] and so forth) of which he gives us an example' (4:401n). Kant continues to speak of respect for persons in the same terms in this memorable vignette from the second Critique:

[B]efore a humble common man in whom I perceive righteousness [Rechtschaffenheit] of character in a higher degree than I am aware of in myself my spirit bows, whether I want it or whether I do not [...]. Why is this? His example holds before me a law that strikes down my self-conceit when I compare it with my conduct, and I see observance of that law and hence its practicability proved before me in fact. (5:76-77)

However, Kant also speaks of respect for persons in another way. And he does so already in the Groundwork. This was noted above, in connection with Kant's taking persons to be 'independently existing' ends: such a being constrains or limits ends, Kant says, and 'is an object of respect' (G 4:428). Intuitively, a person is a proper object of respect regardless of whether he provides, through his shining conduct, an example of the practicability of the requirements of morality. It is precisely this notion of a respect that is due to anyone simply as a person regardless of merit — that Kant goes on to emphasize in his later work. In the Metaphysics of Morals Kant claims that we have a duty to respect persons, simply as persons: 'Every human being has a legitimate claim to respect from his fellow human beings and is in turn bound to respect every other' (MS 6:462). We are placed under such obligation by anyone, regardless of the obligating party's moral merit, or any appraisal thereof $(6: 463) .^{30}$

So far, then, we have a general idea of respect as a readiness to be moved by one's recognition of moral requirement. And we also have what looks to be two distinct notions of respect for persons. One is respect for persons that tracks merit; the other is a respect for 
persons that is due to anyone, regardless of merit. Stephen Darwall has helpfully distinguished the former as 'esteem respect' from the latter as 'recognition respect' (2008; cf. 1977). ${ }^{31}$ My interpretive thesis is that recognition respect is how, on Kant's account, exercises of practical reason are held to the there anyway requirement. If that thesis is correct, then it should follow that recognition respect is involved in any sound exercise of practical cognitive capacities in concreto. This would be so if recognition respect is how we register the relevant facts about the existence of persons, and if thinking well about what one has reason to do involves taking account of such facts in the right way. Esteem respect, by contrast, looks to be an occasional state that might punctuate moral life from time to time; but it hardly seems to be something that is required of one in order for one to make good use of practical cognitive capacities on any given occasion.

Darwall suggests that one way to think of the difference between esteem respect and recognition respect is this: only esteem respect can coherently be conceived as feeling. When Kant introduces a duty to respect persons in the Metaphysics of Morals, Darwall notes, he clearly has recognition respect in mind; therefore, recognition respect must therefore be 'something that we can voluntarily adopt, and therefore not a feeling or a spontaneous attitude like the response to merit' (2008:177). This seems straightforward, but I wonder if it really is. At any rate, if we follow Darwall here, then it becomes unclear how we could take recognition respect to be any kind of receptivity. Now, Darwall allows that esteem respect is a receptivity in the sense that it is an unwilled response to perceived merit. That picks up on Kant's saying that his 'spirit bows' whether he wants it to or not: the attitude is wrung from him. At the same time, with esteem respect, the person of apparently good character stands in for the law. So the respect is not so much a way of being attentive to the particular person, but rather to the law (a universal). Respect for the law is the effect that thinking this universal has on normal human beings, in Kant's view. So it is a feeling 'self-wrought' by reason itself ( $\mathrm{G}$ 4:401n; KpV 5:75-6).

But recognition respect does not seem to me to be an attitude that we can voluntarily adopt, either. We can of course fail to recognize a person as a person — perhaps by treating 
something inessential to personhood (ethnicity, say) as if it were essential. But when we do appropriately recognize a person as a person, we do so in virtue of some very basic moral development. When we do, we are immediately recognizing what is the case — appreciating the relevant facts about the existence of persons — rather than making some kind of choice to see things a certain way, or drawing some kind of inference from the non-moral facts before us (perhaps from the perception of a head, a torso, and some limbs). The attitude is simply wrung form us. That is why I propose that recognition respect be understood as some kind of receptivity to how things are: it is how we recognize here is a person.

An account of recognition respect that stays within recognizable Kantian boundaries would begin by saying that it is rational nature recognizing itself. The next step would be to infer, from that, that it is a matter of recognizing the capacity for a certain kind of thought presumably, the capacity to think about what one has reason to do, and so to set ends and act on them. How does the capacity for such thought recognize itself — or rather, recognize another instance of the same capacity? Presumably by appreciating the possibility of a certain kind of exchange of thought, of giving and asking for reasons: there may be a developed readiness for such an exchange, or there may only be a brute capacity that one is fully warranted to expect will develop into such a readiness (an appreciation which we show, quite naturally, in our relations with infants). If this is right, it is a receptivity that is possible only in relation to the possibility of a certain kind of thought, namely that concerned with what to do.

To recognize here is a person is not itself a thought about what to do. What, then, is its role in practical thought? In $\$ 4.1$, we learned that in Kant's view, such facts constrain choice. But what sort of fact is at issue when I recognize here is a person? Some might be inclined to think that the recognition here is a person furnishes a theoretical premise for practical deliberation: the person is standing right before me, say, as a given particular. Those who are inclined to say this might also allow that practical deliberation requires such putatively theoretical premises — since, after all, facts about the existence of persons constrain choice. Someone who goes this route 
would accordingly not be inclined to think that recognizing here is a person calls for a distinctly practical receptivity: it requires a receptivity trained on spatio-temporal particulars, plus some resources for inferring which of those particulars are likely animated by a noumenal will.

But I reject that facts about the existence of persons are theoretical facts. Facts about the existence of persons constrain choice full stop: they constrain choice regardless of anything I might happen to want or not want, regardless of any end I may set at my own discretion. This is what Kant has in mind when he remarks that a person is an entity 'never to be acted against' and is 'an object of respect'. ${ }^{32}$ The connection between the recognition here is a person and what these constraints on choice are is necessary and immediate: I cannot recognize a person as a person without some appreciation of those requirements. ${ }^{33}$ This does not mean that I will necessarily be sufficiently moved by recognition of those requirements. The torturer recognizes his victim as a person, specifically a human person, even as he seeks to degrade this person by exploiting his characteristically human-person susceptibility to certain forms of suffering, both physical and psychological. If he could not recognize persons as persons, and so his victim as a person, he would in the first place have to be suffering from some severe cognitive disability or mental illness: he would not necessarily be a paragon of vice.

Let me recap. From the constructivist, I accept the efficacy principle. From the realist, I draw the idea that exercises of practical reason must be held to the there anyway requirement. In $₫ 3$, I offered a proposal for how these points could be combined. My proposal chiefly calls for distinguishing the object of practical reason from facts about the existence of persons allowing the latter to satisfy the there anyway requirement, since the former plainly cannot. In $₫ 4$, I have argued that Kant is committed to this distinction; and that we are apprised of these facts through recognition respect, which should be conceived as a distinctly practical receptivity. Next let us consider what we should make of the Kantian conception of practical reason in light of all this. 
5. Rejecting the constructivist's further inference about practical reason

When Kant says that the exercise of practical reason does not merely determine its object but also makes it actual, he points to an exercise of reason that is properly expressed in action and, so expressed, makes actual the object of its determination, which is the good. Following Engstrom (2009), I have been referring to this as practical reason's essential efficacy. This is just the idea of reason in its capacity to exercise causality, which is distinguished from reason in its capacity to think contemplatively about how things are. What I mean to call into question is not the efficacy principle itself, but a further inference that some Kantian constructivists take to follow from it, which is that practical reason must be more radically self-determining than theoretical reason because it need not contend, in its exercise, with what is there anyway. I shall call this the further inference. Here I argue that we should reject the further inference.

\subsection{The further inference about practical reason}

Among the various statements of Kantian constructivism, the one offered by Engstrom (2009) is particularly apt for me to consider, since he admits two basic claims about practical reason that I also endorse here: first, its efficacy; and second, that it is a cognitive capacity issuing in practical knowledge. Engstrom, however, dismisses the there anyway requirement as inappropriate for practical knowledge (2013:143-4). The relevant claims about practical reason - its efficacy and its status as a cognitive capacity — are brought together in the idea that practical knowledge is 'a form of self-knowledge' (2013:145-6). ${ }^{34}$ What sort of self-knowledge is this? It is not introspective self-knowledge, in the sense of some kind of quasi-perceptual awareness of the goings on of one's own mind: to say that would be to take the knowledge to be theoretical in character. What one knows, when one knows what to do, is how to exercise one's own causality. Since practical knowledge brings its own object into being, that can only mean that practical knowledge, qua self-knowledge, realizes or constitutes the self as an agent. ${ }^{35}$ And that, it seems 
to me, implies that on this view the original good to be brought about through action — the most basic fruit of practical reason's efficacy — is the subject's own autonomy.

Engstrom claims that if practical knowledge is knowing how to exercise my own causality, and if this knowledge realizes or constitutes me as an agent, then it necessarily does so in relation to others: 'Practical self-determination is never the bare self-relation of an isolated practical I; it always has a footing in the self-relation of the we of practical knowledge' (2009:123). ${ }^{36}$ The appeal to a 'we' is obviously supposed to be doing some work in rendering the idea of practical self-determination genuinely cognitive. But unless it can be shown that it is impossible or incoherent to care about one's own autonomy without also caring about how one stands, as an agent, in relation to others - whatever exactly the latter relation should involve then I cannot see how the appeal to an I that is also a we can be anything other than an afterthought. Engstrom may well have an advantage over Korsgaard in emphasising, as a basic principle, that practical reason is a cognitive capacity; for this should entail that its selfdetermination can only come through knowledge. But then if knowledge is invoked to avoid arbitrariness, we must also suppose that this knowledge owes allegiance to how things are anyway. Of course this is precisely what constructivists reject: for them, there is no good that is there anyway; and the original good to be brought about through action is one's own autonomy. Thus in the end it is unclear how the insistence that the self-knowledge is not that of 'an isolated practical $I$ ' avoids the implication that, on this conception of practical reason, other persons (at any rate) are incidental to its knowledge.

Perhaps this is too quick: someone might simply point out that Kant's argument for the formula of humanity involves showing that the value of one's own agency is essentially related to that of others. ${ }^{37}$ And that is correct. However, to get that point on board correctly, I also think that we need to reject the further inference about practical reason that is common to this strand of constructivist thinking. I will explain why in $₫ 5.3$. First let us consider what the textual 
evidence for the further inference might be; and I will explain why it does not provides the evidence in question.

\subsection{Textual evidence for the further inference?}

To the best of my knowledge, the Kantian constructivists who have promoted the further inference have not argued for it on textual grounds. But their best evidence might consist of a series of remarks across a set of three passages from the Critique of Practical Reason (5:42-44, 65-66, and 89-91). The topic of these passages is the observation that while the expositions of theoretical and practical reason have the same elements - both, roughly, deal with principles, concepts, and sensibility — they address these topics in precisely the opposite order. These passages all underscore practical reason's efficacy; ${ }^{38}$ and on the face of it they seem to show Kant endorsing the further inference.

In brief, this is the order of exposition for theoretical reason. The theoretical employment of reason involves judging a priori about objects that can only be given in sensible experience. The first Critique begins by arguing that there are a priori sensible representations (pure intuitions), because without demonstrating this there would be no prospect of showing how it is possible to judge in the relevant way. Here Kant reminds us that theoretical reason yields no 'synthetic principles from mere concepts without intuition' (KpV 5:42) — which is to say that theoretical cognition can only relate to its object through the resources of sensibility. So the exposition of theoretical reason begins with an account of sensible representation, then moves to an account of pure concepts of understanding, and establishes the objective validity of these concepts through their relation to pure intuition. From this we get a set of synthetic a priori principles - necessary sources of knowledge about any object in the domain of nature.

By contrast, Kant continues, the object of practical reason is not an object of possible experience; so there can be a derivation of synthetic principles of practical reason without reference to sensible representation. This is why the exposition of the second Critique works in 
the opposite direction — from principles, to concepts, and finally to sensibility. All we need to do, according to the exposition of the second Critique, is find the principle constitutive of practical reason, that without which there can be no rational determination to action at all. From this principle we derive the concept of the object of practical reason. And since practical reason is efficacious, we are faced with no special problem about the objective validity of its principle: the reality of its object will be accounted for through the thought that any such employment of practical reason brings its object into being. The 'sensibility' at issue is respect for law — the felt, and efficacious, recognition of the bindingness of law. It is not, in this context, recognition respect for persons.

What does Kant claim is the object of practical reason? He is explicit: it is a certain disposition of the will — an autonomous one.

[S]ince all precepts of pure practical reason have to do only with the determination of the will, not with the natural conditions (of practical ability) for carrying out its purpose, the practical a priori concepts in relation to the supreme principle of freedom at once become cognitions and do not have to wait for intuitions in order to receive meaning; and this happens for the noteworthy reason that they themselves produce the reality of that to which they refer (the disposition of the will), which is not the business of theoretical concepts. (KpV 5:66)

Kant says here that an exercise of practical reason can issue in knowledge without any involvement of intuition. That, really, is the best prima facie evidence for the further inference: for surely practical reason must be more radically self-determining than theoretical reason if it can have knowledge without 'having to wait for intuitions'. But what is Kant saying, exactly? A cognitive exercise of reason is one that relates to an object. Practical cognition realizes, or brings about, its object. And the object of practical reason is a certain disposition of the will. Crucially, Kant's claim here is restricted to the object of practical reason, the good to be realized in action. Nothing he says here commits him to the view that a sound exercise of practical reason owes no allegiance to what is there anyway, independently of its exercise. The remark still allows for the 
possibility that the only way in which to realize this good — and thereby have practical knowledge — requires attention to the relevant facts about the existence of actual persons.

\subsection{Blocking the further inference}

Now I want to return to the idea that the value of one's agency is essentially related to that of others: this is a result that arguably already emerges from the idea that facts about the existence of persons constrain choice. For Kant, this can only be a mutual constraint: we bind one another, obligate one another, simply by being there. In the Metaphysics of Morals, Kant elaborates on this point in a way that, it seems to me, has yet to reverberate through Kant scholarship as it should. Kant says there that we have duties only to persons that exist; and by that he means actual, empirically available persons.

[A] human being has duties only to human beings (himself and others), since his duty to any subject is moral constraint by that person's will. Hence the constraining (binding) subject must, first, be a person; and this person must, secondly, be given as an object of experience, since the human being is to strive for the end of this person's will and this can happen only in relation to each other of two beings that exist (for a mere thoughtentity cannot be the cause of any result in terms of ends). (6:442; my underscore)

The local point of these remarks is to deny that we can have duties to non-persons (non-rational animals and inanimate nature), and also to deny that we can have duties to persons that cannot be given in experience (such as God). It would presumably also follow that we do not have duties to merely possible persons, like an unconceived child. We have duties to actual persons, persons that exist: such persons are given as objects of experience. ${ }^{39}$

I have been arguing that we are apprised of facts about the existence of persons through recognition respect. We might now ask what exactly it is that recognition respect 'tracks'. Many Kantians will likely suppose that it tracks something general: the personhood of the person, not the particularity of the person. ${ }^{40}$ And there is certainly something right about this from a Kantian systematic perspective: after all, it is not your love of sailing or philosophy on which 
your status as an independently existing end, your unconditioned value as a person, rests. But we also need to be careful here. Unchecked, the default Kantian response risks regarding persons as interchangeable. $^{41}$

What checks it is just the acknowledgement that talk about what practical reason is answerable to, or what recognition respect tracks, goes only so far when it is considered in abstraction from the ground-level, first-personal exercise of such capacities. On any such exercise, a given person registers as an individual, and non-interchangeable. Why is this? The passage just quoted gives us an answer. In it, Kant says that 'the human being is to strive for the end of this person's will', and he says that this can only happen between two really (empirically) existing persons. Why does he say this? If it is the end of another person's will that is at issue, then the duty of beneficence is at issue. This is an imperfect duty, which means that it calls for the free adoption of morally obligatory ends: in this case, the happiness of others. Since it is an imperfect duty, I am not required to make your happiness — in particular — my end. I am only required to make the happiness of others my end: there is latitude as to the happiness of which others this might involve, and what my happiness-promoting actions might turn out to be (MS 6:390ff.). So Kant cannot be saying that the fact of any given person's existence binds me to strive for the end of this person's will — inasmuch as this is his happiness. But he is saying that we have duties only to empirically available persons: only such persons morally bind one another. Why is this? Presumably the answer is that you can only register as the setter of your own ends — as a person — if I recognize you to be an individual, and non-interchangeable. You are not rational nature as such; you a rational being who is also someone in particular. And it is precisely this that opens up the possibility of real deliberation about what to do to honour this fact that you are a person, a setter of your own ends.

If we suppose that recognition respect tracks just the personhood of the person, then nothing obviously stands in the way of our treating persons as interchangeable. This is why recognition respect must be a distinctly practical receptivity. It is what holds practical reason, in 
its sound exercise, to the there anyway requirement, and the constructivist's further inference is blocked.

\section{Conclusion}

If there can be no knowledge of what one has reason to do without appreciating the relevant facts about the existence of persons, then practical reason cannot be distinguished from theoretical reason on the grounds that the there anyway requirement is somehow irrelevant to its sound exercise. Thus I argued for holding exercises of practical reason to this requirement. The result challenges a widespread assumption about Kant's conception of practical reason namely that practical reason is exercised on determinations of states of affairs that are, in themselves, evaluatively neutral. ${ }^{42}$ If I am right, Kantians might take more seriously the possibility that exercises of practical reason must involve a distinctly moral receptivity. For the challenge of moral life, at least as it registers at ground-level, is not to compare one's maxim against the moral law in order to solve some general problem about how to exercise one's causality as an agent. Rather, it is to live in a way that realizes an appropriate appreciation of the value of actual persons. My aim has been to articulate a conception of practical reason that is both recognizably Kantian, and yet fully poised to accommodate this view of why, really, it is hard to live well. ${ }^{43}$

\footnotetext{
${ }^{1}$ Strictly speaking, I am concerned with one strand of contemporary Kantian constructivism that does emphasize this point: not all constructivists do.

${ }^{2}$ The position presented in Engstrom (2009) is first explicitly recognized as constructivist by Engstrom in (2012 and 2013).
} 
${ }^{3}$ Rawls took this to be a consequence of Kant's transcendental idealism (Rawls 2001:99-100). However, transcendental idealism has also been marshalled on the Kantian realist side for an opposing conclusion; see, e.g., Stern (2012:80).

${ }^{4}$ These considerations figure prominently for Korsgaard (1996a and 2008) and Engstrom (2013). For other accounts of the Kantian position as properly anti-realist, see Rauscher (2002) and Johnson (2007).

${ }^{5}$ References to Kant's works follow volume and page of Kants Gesammelte Schriften, 29 vols. (Berlin: Walter de Gruyter [and predecessors], 1900-). An exception is the Critique of Pure Reason, which is cited according to custom by the first and second editions, abbreviated A/B; translations are my own. Other quotations are from the Practical Pbilosophy volume in the Cambridge Edition of the Works of Immanuel Kant (Cambridge University Press, 1996). I use these abbreviations: $\mathrm{G}=$ Groundwork for the Metaphysics of Morals; $\mathrm{KpV}=$ Critique of Practical Reason; MS $=$ Metaphysics of Morals; Prol=Prolegomena to any Future Metaphysics.

${ }^{6}$ 'Here I content myself' with putting the distinction in these terms, Kant says (A633/B661). ${ }^{7}$ As Engstrom (2009:118-19) points out.

${ }^{8}$ See also KpV 5:44, 46; A301-2/B358 and A327-8/B384-5.

${ }^{9}$ See, e.g., Hill (1989:364); or Gaut (1997:162-3), who sketches this on behalf of the Kantian constructivist, and presents Kant as the 'greatest exponent' of the 'value conferral or constructivist model of practical reason' (162). Cf. Bojanowski (2012:18-20), who suggests that Kant's position must be a form of idealism on the basis of practical reason's efficacity.

${ }^{10}$ Korsgaard (1996b:407) notes that it was only beginning with her essays from the early 1990s that she started to gravitate towards the thoroughgoing view.

${ }^{11}$ Arguments for Kantian moral realism can be found in Guyer (1998 and 2000), Langton (2007), Hills (2008), Wood (2008), Galvin (2011), and Stern (2012). Cf. Watkins and FitzPatrick (2002), Kain (2006), and Wilson (2013) for more restricted arguments challenging constructivism's status 
as the best interpretation of key doctrines in Kant's ethics, and interpretive suggestions in favour of realism.

${ }^{12}$ Wood cites the remark about the 'absolute worth of a human being' from G (6:439), in conjunction with Kant's remarks from the Critique of Pure Reason about what it is for something to possess a property 'absolutely' (A324-5/B380-1) to draw the conclusion that this absolute value is 'the sole and sufficient reason why anyone, even God, should judge [human beings] to have [such worth]' (2008:112).

${ }^{13}$ E.g., Korsgaard (1996a:35-44, passim).

${ }^{14}$ Kant distinguishes between duties of narrow and wide obligation, and the point here is somewhat more complicated for the latter. Duties of wide obligation stem from the adoption of morally obligatory ends (which Kant identifies as (a) one's own perfection and (b) the happiness of others). Hence even though wide duties do not command any particular action or omission of anyone in any circumstance, they nevertheless follow from an end that everyone is required to adopt.

${ }^{15}$ For Kant's view of practical reason as a cognitive capacity issuing in moral knowledge, consider KpV (5:19-20), or the heading at G (4:393), to note just a couple of prominent examples. The point has perhaps proved to be more controversial than it should be - perhaps owing to the influence of constructivism, and the tendency to assume that Kantian constructivism must be a form of non-cognitivism. For correctives to this, see Engstrom (2009) and Elizondo (2013).

${ }^{16}$ E.g., G (4:389, 408, 425, 437).

${ }^{17}$ Langton (2007:183) notes how the verb 'determine' in this context obscures the fundamental metaethical disagreement.

${ }^{18}$ E.g., for Korsgaard, there are 'facts about the solutions to practical problems faced by selfconscious rational beings' - for Korsgaard, these problems boil down to a general problem 
about how to realize or constitute ourselves as agents — and these facts lie in the nature of reason itself (Korsgaard 2008:325; cf. 1996a:36). But this is just the extent to which Korsgaard is prepared to allow that moral realism may be true, but true in a way that is 'boring' (2008:325n49) or 'trivial' (1996a:32).

${ }^{19}$ In the next section, I will explain why my position remains neutral in the metaethical debate.

${ }^{20}$ Korsgaard (2008:315; 1996a:36-7, 44-7).

${ }^{21}$ The arbitrariness objection is raised by Regan (2002), and appealed to repeatedly by Stern (2012).

${ }^{22}$ We might wonder how the there anyway requirement could hold even for Kant's account of theoretical cognition: is it at odds with transcendental idealism, and specifically the 'Copernican' thesis presented at the outset of the first Critique (Bxvi-xvii)? Kant takes himself to be entitled to maintain that the objects of theoretical cognition are there anyway, independently of any particular exercise of the relevant cognitive capacities. This is what is at stake when he distinguishes his own transcendental idealism as 'formal' idealism from the varieties of 'material' idealism that he attributes to Descartes and Berkeley (B274-5; B518-9n). Transcendental idealism allows for the there anyway requirement to be met by whatever it is in the objects of theoretical knowledge that accounts for their concrete actuality. It should also be noted that Kant agonised over his own choice of terminology here (see Prol 4:375), which implies that he was aware of a possible tension between his espoused Copernicanism and the there anyway requirement. I cannot assess here whether his attempts to resolve this tension are successful.

${ }^{23}$ Wilson (2013:249-50) makes a similar point.

${ }^{24}$ I am following Gregor's translation here, though it arguably takes liberties in the rendering of selbstständige.

${ }^{25}$ I would like to thank an anonymous referee for this journal for suggesting that I consider this passage. 
${ }^{26}$ See Timmerman (2006:71-73) for an argument that Kant's reference to 'rational nature' at G (4:438) refers to rational beings.

${ }^{27}$ I take up the topic of respect for persons in $\$ 4.2$.

${ }^{28}$ If so, then presumably I cannot adequately recognize a person as a person without some appreciation of those requirements; I return to this in $\$ 4.2$.

${ }^{29}$ See Introduction to the Doctrine of Virtue (MS 6:379-413; and chiefly 6:384-395).

${ }^{30}$ Kant enumerates various duties of recognition respect in the Doctrine of Virtue (MS $\int \$ 37-44$ 6:462-468).

${ }^{31}$ Darwall (2008) treats respect for the moral law as a type of recognition respect. I find this somewhat confusing, since Kant indicates that all respect is ultimately respect for the moral law — suggesting that recognition respect should be a type of respect for the moral law, rather than the other way around. Darwall's thinking, I think, is this: we can distinguish between the moral law and the ideal of perfection (virtue) that is thought through the moral law. Respect for the moral law aligns with respecting persons simply in virtue of possessing practical reason, since the moral law is the principle constitutive of this capacity. At any rate, in my usage here, 'recognition respect' refers to respect for persons simply as persons (regardless of merit).

Another departure from Darwall might be noted here. Darwall takes recognition respect to be a mode of acknowledging the rational nature of persons. In the course of developing my positive proposal (in \5), I take recognition respect to be the acknowledgement of persons as rational beings who are at the same time given as objects of experience. Thanks to an anonymous referee for this journal for suggesting this clarification.

${ }^{32} \mathrm{G}$ (4:437 and 4:428), as already noted and discussed in $\$ 4.1$.

${ }^{33}$ Cf. Church (2013:197) and Geiger (2011:295-296) on Kantian moral perception.

${ }^{34}$ Or: 'The original concept of an object of theoretical knowledge is of something that, existing independently of the knowledge of it, must in order to be known be 'given from elsewhere' by 
affecting the senses (something that can appear) and so not necessarily the subject itself; the original concept of an object of practical knowledge, on the other hand, is always of the subject itself, but conceived, and thereby constituted, as agent' (Engstrom 2009:121).

${ }^{35}$ See Engstrom as quoted in n34. Korsgaard (2008:193 and 2009:131) makes essentially the same point, while (it seems to me) studiously avoiding framing it in terms of practical knowledge. ${ }^{36}$ See also Engstrom (2013:149). Compare Thomas Nagel's objection to Korsgaard, and her reply, both in Korsgaard (1996a:206 and 246).

${ }^{37}$ I thank an anonymous referee for this journal for raising this point.

${ }^{38}$ Most vividly the third: 'Practical reason [...] does not have to do with objects for the sake of cognizing them [zu erkennen] but with its own ability to make them real (conformably with cognition of them)' (5:89).

${ }^{39}$ Prima facie, this passage stands in tension with Kant's suggestion that a person is essentially a noumenal will, e.g., at G (4:451-2); I cannot attempt a resolution to this here.

${ }^{40}$ I thank an anonymous referee for this journal for raising the issue in these terms.

${ }^{41}$ Timmerman (2006:75) nicely links the respect that persons are due owing to their status as 'beings whose existence is valuable as such, which makes them individual and noninterchangeable' — though the point is made only in passing, and unfortunately not elaborated. ${ }^{42}$ See Brewer (2010) for insightful discussion of this conception of practical reason. One of my aims, however, has been to deny that Kantians have to accept it; others, such as Herman (1993; 2007), have made arguments in a similar spirit, but focusing on different issues.

${ }^{43}$ I must express my deep gratitude to Markos Valaris, who patiently discussed this paper with me many times, and commented on its many versions (and ancestors); and to Jochen Bojanowski and Sasha Newton for tireless discussion of the topic of this paper during a visit to Leipzig in 2013 - the express occasion of which visit was a symposium on Stern (2012), and I am grateful to Robert Stern for his intellectual honesty, and patience, with our questions about Kantian 
moral realism. Thanks to Janelle DeWitt and two anonymous referees for this journal for incisive written comments. Versions of this paper were presented at meetings of the North American Kant Society (Philadelphia, 2014) and the Australasian Association of Philosophy (Canberra, 2014): thanks to the audiences on those occasions. Research for this article was supported by a grant from the Australian Research Council (DP130100172). 


\section{REFERENCES}

Brewer, Talbot (2010) 'Two Pictures of Practical Thinking'. In Lawrence Jost and Julian Wuerth (eds.), Perfecting Virtue: New Essays on Kantian Ethics and Virtue Ethics (Cambridge: Cambridge University Press), pp. 116-146.

Bojanowski, Jochen (2012) 'Is Kant a Moral Realist?'. Kant Yearbook, 4, 1-22.

Church, Jennifer (2013) Possibilities of Perception. Oxford: Oxford University Press.

Darwall, Stephen (1977) 'Two Kinds of Respect'. Ethics, 88, 36-49.

Darwall, Stephen (2008) 'Kant on Respect, Dignity, and the Duty of Respect'. In Monika Betzler (ed.), Kant's Ethics of V irtue (Berlin: de Gruyter), pp. 175-200.

Elizondo, E. Sonny (2013) 'Reason in its Practical Application'. Philosophers' Imprint, 13, 1-17.

Engstrom, Stephen (2009) The Form of Practical Knowledge: A Study of the Categorical Imperative Cambridge, MA: Harvard University Press.

Engstrom, Stephen (2012) 'Bringing Practical Knowledge into View: Response to Bagnoli, Hill and Reath'. Analytic Philosophy, 53, 89-97.

Engstrom, Stephen (2013) 'Constructivism and Practical Knowledge'. In Carla Bagnoli (ed.), Constructivism in Ethics (Cambridge: Cambridge University Press), pp. 133-154.

Formosa, Paul (2013) 'Is Kant a Moral Constructivist or a Moral Realist?'. European Journal of Philosophy, 21, 170-196.

Galvin, Richard (2011) 'Rounding up the Usual Suspects: Varieties of Kantian Constructivism in Ethics’. The Philosophical Quarterly, 61, 16-36.

Gaut, Berys (1997) 'The Structure of Practical Reason’. In Garrett Cullity and Berys Gaut (eds.), Ethics and Practical Reason (Oxford: Clarendon Press), pp. 161-188.

Geiger, Ido (2011) 'Rational Feelings and Moral Agency’. Kantian Review, 16, 283-308.

Guyer, Paul (1998) 'The Value of Reason and the Value of Freedom’. Ethics, 109, 22-35.

Guyer, Paul (2000) 'Kant's Morality of Law and Morality of Freedom'. In Kant on Freedom, Law, and Happiness (Cambridge: Cambridge University Press), pp. 129-171.

Herman, Barbara (1993) The Practice of Moral Judgment. Cambridge, MA: Harvard University Press.

Herman, Barbara (2007) Moral Literacy. Cambridge, MA: Harvard University Press.

Hill, Thomas E. (1989) 'Kant's Theory of Practical Reason'. Monist, 72, 383-383.

Hills, Allison (2008) 'Kantian Value Realism'. Ratio, 21, 182-200. 
Johnson, Robert N. (2007) 'Value and Autonomy in Kantian Ethics'. Oxford Studies in Metaetbics, $2,133-148$.

Kain, Patrick (2006) 'Realism and Anti-Realism in Kant's Second Critique'. Philosophy Compass, 1, 449-465.

Korsgaard, Christine (1996a) Sources of Normativity. Cambridge: Cambridge University Press.

Korsgaard, Christine (1996b) Creating the Kingdom of Ends. Cambridge: Cambridge University Press.

Korsgaard, Christine (2008) The Constitution of Agency. New York: Oxford University Press.

Korsgaard, Christine (2009) Self-Constitution: Agency, Identity, Integrity. New York: Oxford University Press.

Langton, Rae (2007) 'Objective and Unconditioned Value'. Philosophical Review, 116, 157-185.

Rauscher, Frederick (2002) 'Kant's Moral Anti-Realism'. Journal of the History of Philosophy, 40, 47799.

Rawls, John (2011) Political Liberalism (expanded edition). New York: Columbia University Press.

Sayre-McCord, Geoffrey (1988) 'Introduction: The Many Moral Realisms'. In Geoffrey SayreMcCord (ed.), Essays on Moral Realism (Ithaca: Cornell University Press), pp. 1-26.

Regan, Donald (2002) 'The Value of Rational Nature'. Ethics, 112, 267-291.

Stern, Robert (2012) Understanding Moral Obligation. Cambridge: Cambridge University Press.

Timmermann, Jens (2006) 'Value without Regress: Kant's “Formula of Humanity” Revisited'. European Journal of Philosophy, 14, 69-93.

Watkins, Eric and William FitzPatrick (2002) 'O’Neill and Korsgaard on the Construction of Normativity'. The Journal of V alue Inquiry, 36, 349-367.

Wilson, Eric (2013) 'Kant on Autonomy and the Value of Persons'. Kantian Review, 18, 241-262.

Wood, Allen (2008) Kantian Ethics. Cambridge: Cambridge University Press. 